\title{
Piglets' Intestinal Microflora Fed with a Plants Mix
}

\author{
Gabriela Maria CORNESCU*, Tatiana PANAITE, Teodor GAVRIS, Cristina TABUC, Margareta OLTEANU \\ and Rodica Diana CRISTE
}

National Research-Development Institute for Animal Biology and Nutrition, Calea Bucuresti no. 1, 077015, Balotesti, Romania

*Corresponding author: gabriela_cornescu@yahoo.com

Bulletin UASVM Animal Science and Biotechnologies 75(2)/ 2018

Print ISSN 1843-5262; Electronic ISSN 1843-536X

DOI:10.15835/buasvmcn-asb: 2018.0021

\begin{abstract}
The objective of this study was to evaluate the effect of a plant mix (bilberry, black currant, quince, peppermint and fennel essential oil) inclusion into the diets of piglets (18-45 kg) on intestinal microflora equilibrium. An experiment was performed on 8 castrated hybrid TOPIGS $(18.69 \pm 1.25 \mathrm{~kg})$ divided in 2 groups $(\mathrm{C}$ and $\mathrm{E})$. The piglets were kept in an experimental house in individual metabolic cages. Compared to the conventional diet (18\% crude protein and $3214 \mathrm{kcal} / \mathrm{kg}$ metabolic energy) of group C, the diet of E group had included $789 \mathrm{mg}$ mixture of plants $/ \mathrm{kg}$ feed. At the final of the experiment the piglets were slaughtered and digesta samples were collected from jejunum and ileum for microbiological analysis. For jejunum, a significant $(\mathrm{P}<0.05)$ decrease of Staphylococci spp. $\left(\log _{10} \mathrm{CFU} / \mathrm{g}\right)$ concentration in E group was noticed correlated strongly negative with a statistically significant $(\mathrm{P}<0.05)$ increasing concentration of Lactobacillus spp. $\left(\log _{10} \mathrm{CFU} / \mathrm{g}\right)$ concentration. The results were similar for ileum. This dietary mixture of plants had some effects on microbial population of piglets' jejunum and ileum to help positively the intestinal changes of microbiota.
\end{abstract}

Keywords: diet, microbiota, jejum, ileum , swine

\section{INTRODUCTION}

Overall health of young piglets has serious implications on performances, efficiency and economic losses. Gut microflora has significant effects on animal nutrition, health, and growth performance by interacting with nutrient utilization and the development of gut system of the animal (Hashemi and Davoodi, 2011).

The pigs' gastrointestinal microbiota has been studied to increase production efficiency, to improve products quality and help attempt to reduce disease. Gastrointestinal parameters and intestinal microflora are important markers of health status and nutrients metabolism in the animal organism (Lokesh et al., 2012).

Understanding the variations of microflora composition is crucial for a reduction antibiotics use in animal production, which are the main points of interest for improved animal health care and welfare and for consumer health protection (Vincenzo Motta et al., 2017).

To eliminate the suspicions concerning the antibiotics usage as growth promotor, to decrease residual meat contamination, to lower the environmental pollution, lots of studies focused on a wide variety of herbs, spices, and essential oils (Windisch et al., 2008).

Therefore as a result of these studies, antioxidant/antimicrobial/growth-promotor effects in pigs were demonstrated corroborated with an enhanced imunity and a digestibility increasing (Basmacioglu et al., 2004, Wei and Shibamoto, 2007). It is considered that natural feed components and herbs can sustain animal health, diminishing this way the number of disease outbreaks on a farm and helping to restrict the use of antibiotics. 
Bilberry (Vaccinium myrtillus L.) have been reported to show direct antimicrobial effects against human pathogens, including Salmonella and Staphylococcus aureus (Puupponen-Pimiä et al., 2005 a,b). In a recent study of wild berries, bilberry juice inhibited adhesion of Streptococcus pneumoniae to human bronchial (Calu-3) cells, and bilberry juice also inhibited growth of S. pneumoniae (Huttunen et al., 2010).

Esposito et al. (2015) consider black currant (Ribes nigrum L.) a rich source of anthocyanins; however, the relationship between their apparently limited bioavailability and significant protection against metabolic pathologies is poorly understood.

Quince (Cydonia oblonga) was to little investigate as fruit waste source for animal feeding, although numerous nutritional human studies were done concerning the identification and quantification of the phenolic compounds. Fattouch et al. (2007) examined the antimicrobial activity of fruit aqueous acetone extracts against different microorganism strains and stated that quince peel extract was the most active for inhibiting bacteria growth with minimum inhibitory and bactericide concentrations in the range of $10^{2}-5 \times 10^{3} \mu \mathrm{g}$ polyphenol/mL.

Essential oils and aromatic plants are well known to exert antibacterial, antifungal and antiviral activity in in vitro and in vivo experiments, inhibiting effects against pathogens such as $C$. perfringens, E. coli or Eimeria species and contributing to an improved intestinal integrity and protection against enteric disease (Windish et al., 2008).

Fennel (Foeniculum vulgare mil.) essential oil has very strong antioxidant, antimicrobial, and hepatoprotective activity (Ruberto et al., 2000; Ozbek et al., 2003). According to Schöne et al. (2006) in some nutritional studies fennel oil significantly decreased the feed intake of piglets.

Peppermint (Mentha piperita) essential oil was often used in pigs' experiment in oil blends (peppermint, anise and clove) as Maenner et al. (2011) used in weaner pigs diets with no effect on body weight gain, feed intake and gastrointestinal microbiota. Improvements of feed conversion ratio and amino acids digestibility were observed.

The objective of this study was to examine the effect of a plant mix inclusion (bilberry, black currant, quince, peppermint and fennel essential oil) with antibacterial properties into the diets of piglets $(18-45 \mathrm{~kg})$ on their intestinal microflora equilibrium, improving/maintaining the production parameters.

\section{MATERIALS AND METHODS}

The study protocol was approved by the Ethical Committee of the National ResearchDevelopment Institute for Animal Nutrition and Biology, Balotesti, IBNA Romania. The experiment has been carried out within IBNA experimental center facilities for 28 days, on 8 hybrid Topigs castrated males [(Large WhitexPietrain)female $\times$ (Talent)-male]. Pigs were divided into 2 homogenous groups (C, E). The animals were housed in individual metabolic cages (Agrico, Rybarska, Czech Republic) with an area of 0.87 $\mathrm{m}^{2}$ with an average initial weight $18.75 \pm 1.71$ $\mathrm{kg}$ for $\mathrm{C}$ group and $18.63 \pm 0.85 \mathrm{~kg}$ for E group. The compound feeds formulations (Tab. 1) were isoenergetic and isoprotein and consisted of corn, wheat, rice, soybean meal, rapeseed meal, gluten, powder milk, sunflower oil, choline premix, Zoofort (a vitamin-mineral premix IBNA's brand) in agreement with TOPIGS requirements.

The E group diet aimed to improve intestinal gut dysfunctions of young piglets using a mixture of plants and oils added into the basic feeding formula of C group (789 mg/kg feed).

The plants mixture (a mix of bilberry dried fruits, black currant dried fruits, quince dried fruits, peppermint and fennel essential oil) are originated from Romania so it could be easy to provide them for current animal feeding practices by the small farmers. Their chemical composition was analysed within laboratory of chemistry and nutrition physiology of INCDBNA (tab. 2).

Pigs were given ad libitum access to water and feed. They were individually weighed at the beginning, weekly and at the end of trial. The average daily gain (ADG), average daily feed intake (ADFI), and gain-feed ratio (G:F) were calculated. The microclimate parameters (temperature and humidity) were monitored. Feed consumption was recorded daily per pig.

The chemical analyses of the feed ingredients were done in the laboratory of chemistry and nutrition physiology of INCDBNA. The following physical-chemical methods have been used to characterise the feed ingredients and the compound feeds samples: dry matter (DM) gravimetric method SR ISO 6498:2001; crude 
Table. 1. Formulation of the experimental compound feed

\begin{tabular}{|c|c|}
\hline Specification & Feeding formula \\
\hline Corn, $\%$ & 45.96 \\
\hline Wheat, $\%$ & 10 \\
\hline Rice bran, \% & 10 \\
\hline Soybean meal, \% & 8 \\
\hline Rapeseed meal, \% & 13 \\
\hline Powder milk & 5 \\
\hline Gluten, $\%$ & 2 \\
\hline Oil, \% & 1 \\
\hline Lysine, \% & 0.5 \\
\hline Methionine, $\%$ & 0.1 \\
\hline Calcium carbonate, $\%$ & 1.75 \\
\hline Monocalcic phosphate, $\%$ & 1.4 \\
\hline Salt, $\%$ & 0.2 \\
\hline Choline, $\%$ & 0.09 \\
\hline Zoofort ${ }^{*}, \%$ & 1.00 \\
\hline Total & 100.00 \\
\hline \multicolumn{2}{|c|}{ Calculated nutrients ( $\mathrm{g} / \mathrm{kg}$ feed) } \\
\hline Dry matter, $\%$ & 90.94 \\
\hline Metabolisable energy, kcal/kg & 3214.00 \\
\hline Crude protein, $\%$ & 18.00 \\
\hline Crude fat, $\%$ & 5.00 \\
\hline Crude fiber, $\%$ & 5.42 \\
\hline Calcium, \% & 1.02 \\
\hline Phosphorus, \% & 0.75 \\
\hline
\end{tabular}

Note: * Vitamin mineral-premix; Ingredients per kilogram of diet: 10000 IU vitamin A, 2000 IU vitamin $\mathrm{D}_{3}, 30$ IU vitamin E, 3 mg vitamin $\mathrm{K}_{3}$, 2 mg vitamin $B_{1}, 6$ mg vitamin $B_{2}, 13.5$ mg d-pantothenic acid, 20 mg nicotinic, 3 mg vitamin $B_{6}, 0.06$ mg vitamin $B_{7} 0.8$ mg vitamin $B_{9} 0.05$ mg vitamin $\mathrm{B}_{12}, 10 \mathrm{mg}$ vitamin $\mathrm{C}, 30 \mathrm{mg}$ vitamin $\mathrm{Mn}, 110 \mathrm{mg} \mathrm{Fe}, 25 \mathrm{mg} \mathrm{Cu}, 100 \mathrm{mg} \mathrm{Zn} 0.38 \mathrm{mg} \mathrm{I}, 0.36 \mathrm{mg}$ Se, $0.3 \mathrm{mg}$ Co, $60 \mathrm{mg}$ antioxidant.

Table. 2. Chemical composition of analysed plants mixture

\begin{tabular}{lc}
\hline \multicolumn{1}{c}{ Specification (\%) } & Plant mixture \\
\hline Dry matter & 92.89 \\
\hline Crude protein & 7.03 \\
\hline Ether extract & 3.74 \\
\hline Crude fibre & 14.02 \\
\hline Crude fat & 11.96 \\
\hline Calcium & 0.24 \\
\hline Phosphorus & 0.25 \\
\hline
\end{tabular}


protein (PB) - Kjeldhal method, Regulation (CE) nr. 152 /2009 and SR EN ISO 5983-2:2009, using a semiautomatic KJELTEC auto 2300 - Tecator (Sweden); ether extractives (EE) - extraction in organic solvents - Regulation (CE) nr. 152 /2009 and SR ISO 6492:2001, using an automatic system SOXTEC 2055 - Tecator (Sweden); crude fibre (CF) - method with intermediary filtration - Regulation (CE) nr. 152 /2009 and SR EN ISO 6865:2002, using FIBERTEC 2010 system-Tecator (Sweden); crude ash (Ash) - gravimetric method - Regulation (CE) nr. 152 /2009 and SR EN ISO 2171:2010, using calcination oven Caloris CL 1206; metabolisable energy (ME) - was calculated from the chemical composition. Microbial populations from jejunum and ileum content samples were determined by counting the colonies on selected media for each microorganism. The analysis of Escherichia coli (E. coli) consists of the successive sowing of the sample in Durham fermentation tube tubes and the band for identifying the indole in the lauryl sulphate medium followed by incubation at $44^{\circ} \mathrm{C}$ for 24-48 h. It is usually run 3 dilutions/sample and seed three test tubes/dilution. The positive tubes were scored and the number of E. coli colonies according to the McCrady table. The result is expressed as the number of $E$. coli colonies $/ 1 \mathrm{~g}$ produced.

The analysis of Salmonella bacteria consists in sowing the sample to be analysed on preimmigration media (selenite-cystine medium) followed by incubation for $24 \mathrm{~h}$ at $37^{\circ} \mathrm{C}$, then performing grooving with selective media (Mac Conckey medium and Rambach medium), at least 2 Petri dishes each medium, and incubated for $24-48 \mathrm{~h}$ at $37^{\circ} \mathrm{C}$. After incubation, the boxes are analysed on Mac Conckey Salmonella environment, transparent, colourless (slightly colourless) transparent are formed on Rambach's medium form red, violet, round, humid, slightly bulging colonies.

The analysis of Staphylococcus spp. consists in submerging $10 \mathrm{~g}$ of the product in liquid hyperchlorinated medium and in sowing from successive dilutions $\left(10^{-3}-10^{-8}\right)$ either on solid medium or on selective medium for Staphylococcus spp. (Baird Parker medium with egg yolk and sodium tellurite); incubation at $37^{\circ} \mathrm{C}$ for $24-48$ hours, followed by counting of colonies developed (only boxes containing 30-300 colonies are considered), the arithmetic mean of the number of colonies in the boxes of the same dilution is calculated, multiplied by the dilution said. The result is expressed as number of germs/1 $\mathrm{g}$ of product.

The Lactobacillus spp. analysis consists in immersing $10 \mathrm{~g}$ of the product in liquid MRS medium and then sowing from successive dilutions $\left(10^{-8}-10^{-9}\right)$ on MRS agar and incubating at $37^{\circ} \mathrm{C}$ for $24-48$ hours, followed by counting of the developed colonies, calculate the arithmetic mean of the number of colonies in the boxes of the same dilution, multiply with that dilution. The result is expressed as the number of lactic bacteria/1 $\mathrm{g}$ of product. All microbiological concentrations were subjected to base-10 logarithm transformation before analysis.

The data obtained were analysed using StatView software. One-way analysis of variance (ANOVA) was used to evaluate statistical significance of differences between dietary treatments. The results are given as means and standard error of the mean (SEM). Differences were considered significant at $\mathrm{P}<0.05$.

\section{RESULTS AND DISCUSSIONS}

Figure 1 shows no significant differences $(\mathrm{P}>0.05)$ between the two groups concerning the final weight of the piglets, $C$ group had $45 \pm 2.68 \mathrm{~kg}$ and $\mathrm{E}$ group had $45.25 \pm 0.96 \mathrm{~kg}$.

The feed conversion had a slightly lower value for E group (2.25 \pm 0.33 ), but without significant differences $(\mathrm{P}>0.05)$ compared to $\mathrm{C}$ group $(2.30 \pm 0.36)$. In general, the plants mix inclusion appear to have no effect on final body weight nor feed conversion. In a literature review, Panagiotis (2017) observed a feed conversion improvement when essential oils were used in monogastric experiments. Improve nutrient utilization and animal performance were observed by Viveros et al., (2011); Dueñas et al., (2015); Brenes et al., (2016) when using phenolic compounds sources in piglets feed.

Weight gain, feed conversion of pigs fed essential oils was essentially equal to that of pigs fed antibiotics. The improved performance appeared to be mediated by improvements in dry matter and protein digestibility arising from improvements in intestinal morphology (Li et al., 2012). 
When plant extract are used a swine gut health is correlated with growth performances. Regarding this matter, Vigors et al. (2016) reported a correlation between high feed efficiency and increased abundance of Lactobacillus spp. in the caecum of pigs.

Within table 3 it was noticed a significant $(\mathrm{P}=0.026)$ decrease in jejunum of Staphylococcus spp. concentration and a statistically very significant $(\mathrm{P}<0.0001)$ increasing concentration of Lactobacillus spp. on E group compared to C group. On the entire experimental period, regarding both groups a strongly negative correlation $(\mathrm{r}=-$ 0.864) it was noticed between the decreasing concentration of Staphylococcus spp. and the increasing concentration of Lactobacillus spp. concentration. Also, it was registered a lower value of E. coli concentration on E group but without statistical significance ( $\mathrm{P}>0.05)$.

It is proven that phenolic compounds (cyanidin, pelargonidin, delphinidin, etc) from sources as black currant, elderberry fruit, blackberries have bactericidal (Gordon and Wareham, 2010) and bacteriostatic properties (Etxeberria et al., 2013), they minimize the adhesion of pathogenic bacteria (E. coli, Clostridium), inhibit the progression of infections in the digestive tract.

By enhancing the proliferation of beneficial bacteria (Bacillus spp., Lactobacillus spp.) and stabilizing gut microflora, polyphenols indirectly

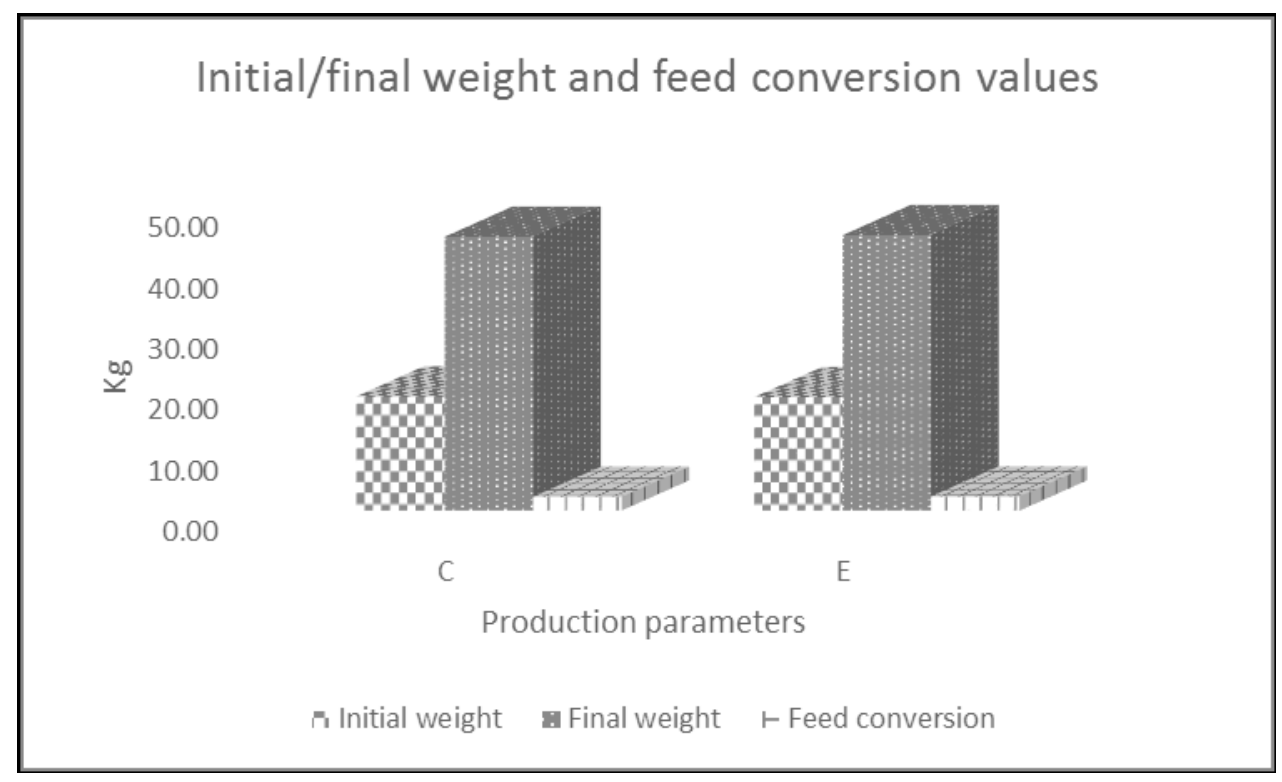

Figure 1. Growth performances values of the experiment

Table. 3. The effect of plants mixture from pigs' diet on jejunum microflora

\begin{tabular}{lcccc}
\hline \multicolumn{1}{c}{ Specification } & Control & Experimental & SEM & P-value \\
\hline E. coli $\left(\log _{10} \mathrm{CFU} / \mathrm{g}\right)$ & 4.096 & 4.081 & 0.008 & 0.364 \\
\hline Salmonella spp. $\left(\log _{10} \mathrm{CFU} / \mathrm{g}\right)$ & absent & absent & - & - \\
\hline $\begin{array}{l}\text { Staphylococcus spp. } \\
\left(\log _{10} \mathrm{CFU} / \mathrm{g}\right)\end{array}$ & $3.637^{\mathrm{a}}$ & $3.519^{\mathrm{b}}$ & 0.028 & 0.026 \\
\hline Lactobacillus spp. $\left(\log _{10} \mathrm{CFU} / \mathrm{g}\right)$ & $5.018^{\mathrm{b}}$ & $5.105^{\mathrm{a}}$ & 0.017 & $<0.0001$ \\
\hline
\end{tabular}

Note: *Values with the different superscript in the same raw are significantly different $(P<0.05)$. 
enhance the host's immune system and overall health (Hashemi and Davoodi, 2011; Paszkiewicz et al., 2012). They can exert a positive influence on gut morphology and improve nutrient absorption in monogastric animals (Kamboh et al., 2015). Also, Lactobacillus spp., are the most commonly used microorganisms as probiotics because of the perception that they are desirable members of the intestinal microflora and because these bacteria have "Generally Recognized As Safe" (GRAS) status (Shokryazdan, 2014).

Within table 4 the microbiological analyses from ileum showed a very significant statistically $(\mathrm{P}<0.0001)$ lower concentration of Staphylococcus spp. and a significantly higher concentration of Lactobacillus spp. $(\mathrm{P}=0.01)$ in E compared with $\mathrm{C}$ group. On the entire trial, regarding both groups, a strongly negative correlation ( $\mathrm{r}=-0.8447)$ it was noticed between the decreasing concentration of Staphylococcus spp. and the increasing concentration of Lactobacillus spp. concentration. Also, a reduction tendency of $E$. coli concentration in the $\mathrm{E}$ group was noticed $(\mathrm{P}=0.062)$.

A very strong relation between production of antimicrobial compounds by lactobacilli and, therefore, prevention of pathogenic microorganisms such as Salmonella, E. coli and Clostridia was also observed in previous studies (Naaber et al., 2004; Coconnier-Polter et al., 2005; Bernbom et al., 2006). Succession of Lactobacillus spp. in the ileum largely depends on their growth rate and ability to adhere the intestinal mucus layer, thus avoiding the "wash-out" effect of the digesta flow (Tannock, 1995).

Jamroz and Kamel (2002) suggested that supplementation with plant extracts increases the digestibility of nutrients and promotes a balanced microflora. This reduces the potential for adhesion of pathogens to the intestinal epithelium, representing one of mechanisms by which the symbiotic acts.

According to Fuller et al. (1989), beneficial bacteria would be favoured in the gastrointestinal tract, preventing colonization of pathogenic bacteria in the mucosa.

\section{CONCLUSION}

The experiment demonstrated that the pigs ate the feed with the plant mixture without any sign of taste dislike or reduction of feed intake reflected in similar performances with control group. Also, this experiment demonstrated that this mixture of plants included in piglets' diet had some effects on microbial population of jejunum and ileum, therefore it can be used to help positively the changes of the intestinal microbiota.

Acknowledgments. This work was supported by a grant of the Romanian Ministry for Scientific Research and Innovation, project number PN 18200102.

\section{REFERENCES}

1. Basmacioglu H, Tokusoglu Ö, Ergül M (2004). The effect of oregano and rosemary essential oils or alphatocopheryl acetate on performance and lipid oxidation of meat enriched with n-3 PUFA's in broilers. South African Journal of Animal Science, 34(3).

2. Bernbom N, Licht TR, Brogren $\mathrm{CH}$, Jelle B, Johansen $\mathrm{AH}$, Badiola I, Vogensen FK, Norrung B (2006). Effects of Lactococcus lactis on composition of intestinal microbiota: role of Nisin. Appl. Environ. Microbiol., 72:239-244

3. Brenes A, Roura E (2010). Essential oils in poultry nutrition: Main effects and modes of action. Animal Feed Science and Technology, 158(1-2), 1-14.

4. Brenes A, Viveros A, Chamorro S, Arija I, (2016). Use of polyphenol-rich grape by-products in monogastric nutrition. A review. Anim. Feed. Sci. Tech., 211: 1-17.

Table. 4. The effect of plants mixture from pigs' diet on ileum microflora

\begin{tabular}{lcccc}
\hline \multicolumn{1}{c}{ Specification } & Control & Experimental & SEM & P-value \\
\hline E. coli $\left(\log _{10} \mathrm{CFU} / \mathrm{g}\right)$ & 6.258 & 5.586 & 0.186 & $0.062^{T}$ \\
\hline Salmonella $\left(\log _{10} \mathrm{CFU} / \mathrm{g}\right)$ & $\mathrm{absent}$ & $\mathrm{absent}$ & - & - \\
\hline Staphylococcus spp. $\left(\log _{10} \mathrm{CFU} / \mathrm{g}\right)$ & $6.183^{\mathrm{a}}$ & $5.708^{\mathrm{b}}$ & 0.090 & $<0.0001$ \\
\hline Lactobacillus spp. $\left(\log _{10} \mathrm{CFU} / \mathrm{g}\right)$ & $6.212^{\mathrm{b}}$ & $6.240^{\mathrm{a}}$ & 0.006 & 0.01 \\
\hline
\end{tabular}

Note: *Values with the different superscript in the same raw are statistically different $(P<0.05)$;

${ }^{\mathrm{T}}$ denote a tendency that the results were influence by treatment $(P<0.10)$. 
5. Coconnier-Polter MH, Moal VLL, Servin A L (2005). A Lactobacillus acidophilus strain of human gastrointestinal microbiota origin elicits killing of enterovirulent Salmonella enterica serovar typhimurium by triggering lethal bacterial membrane damage. Appl. Environ. Microbiol., 71:6115-6120.

6. Dueñas M, Muñoz-Gonzales I, Cueva C, Jimenez-Giron A, Sanchez-Patan F, Santos-Buelga C, Bartolome B, (2015) A survey of modulation of gut microbiota by dietary polyphenols. Bio. Med. Res. Int., ID 850902, 15 pp.

7. Esposito D, Damsud T, Wilson M, Grace MH, Strauch R, Li X, Lila MA, Komarnytsky S. (2015). Black currant anthocyanins attenuate weight gain and improve glucose metabolism in diet-induced obese mice with intact, but not disrupted, gut microbiome. J Agric Food Chem., Jul 15; 63(27):6172-80. doi: 10.1021/acs.jafc.5b00963.

8. Etxeberria U, Fernandez-Quintela A, Milagro FI, Aquirre L, Martinez JA, Portillo MP (2013). Impact of polyphenols and polyphenol-rich dietary sources on gut microbiota composition. J. Agr. Food. Chem., 61: 9517-9533.

9. Fattouch S, Caboni P, Coroneo V, Tuberoso CIG, Angioni A, Dessi S, Marzouki N, Cabras P (2007). Antimicrobial activity of tunisian quince (Cydonia oblonga Miller) pulp and peel polyphenolic extracts. J. Agric. Food Chem., 55 (3), pp 963-969.

10. Fuller MF, McWilliam R, Wang T, Giles LR (1989). The optimum dietary amino acid pattern for growing pigs: 2.Requirements for maintenance and for tissue protein accretion. British Journal of Nutrition, 62(2), 255-267.

11. Gordon NC, Wareham, DW (2010). Multidrug-resistant acinetobacter baumannii: mechanisms of virulence and resistance. International Journal of Antimicrobial Agents, 35(3), 219-226.

12. Hashemi SR, Davoodi H (2011). Herbal plants and their derivatives as growth and health promoters in animal nutrition. Veterinary research communications, 35(3), 169-180.

13. Huttunen S, Toivanen M, Arkko S, Ruponen M, TikkanenKaukanen C (2010). Inhibition activity of wild berry juice fractions against Streptococcus pneumoniae binding to human bronchial cells. Phytotherapy Research, Wiley, 25 (1), pp.122

14. Kamboh AA, Arain MA, Mughal MJ, Zaman A, Arain ZM, Soomro AH (2015). Flavonoids: Health promoting phytochemicals for animal production-A review. J. Anim. Health Prod, 3(1), 6-13.

15. Li PF, Piao XS, Ru YJ, Han X, Xue LF, Zhang HY (2012). Effects of adding essential oil to the diet of weaned pigs on performance, nutrient utilization, immune response and intestinal health. Asian-Aust J Anim Sci. 2012, 25: 1617 1626. 10.5713/ajas.2012.12292.

16. Lokesh G, Ananthanarayan SR, Murthy VN (2012). Changes in the activity of digestive enzymes in response to chemical mutagen diethyl sulfate in the silkworm, Bombyx mori L. (Lepidoptera: Bombycidae). Asian J. App. Sci. 5, 431-437.
17. Maenner K, Vahjen W, Simon O (2011). Studies on the effects of essential-oil-based feed additives on performance, ileal nutrient digestibility, and selected bacterial groups in the gastrointestinal tract of piglets. J. Anim. Sci., 89, 2106-2112.

18. McCrady MH (1915).The numerical interpretation of fermentation-tube results. J Infect Dis 17, 183-212.

19. Motta V, Trevisi P, Bertolini F (2017). Exploring gastric bacterial community in young pigs. Smidt H, ed. PLOS ONE. 12(3):e0173029. doi:10.1371/journal.pone.0173029.

20. Naaber P, Smidt I, Stsepetova J, Brilene T, Annuk H, Mikelsaar M (2004). Inhibition of Clostridium difficult strains by intestinal Lactobacillus species. J. Med. Microbiol. 53:551-554.

21. Ozbek H, Ugras S, Dulger H, Bayram I, Tuncer I, Ozturk G (2003) Hepatoprotective effect of Foeniculum vulgare essential oil. Fitoterapia; 74:317-319.

22. Paszkiewicz M, Budzynska A, Rozalska B, Sadowska B (2012). Immunomodulacyjna rola polifenoli roślinnych. Postępy Hig. Med. Dosw., 66: 637-646.

23. Puupponen-Pimià R, Nohynek L, Alakomi HL, OksmanCaldentey KM (2005b) Theaction of berry phenolics against human intestinal pathogens. Biofactors, 23:24351. [PubMed]

24. Puupponen-Pimiä R, Nohynek L, Alakomi HL, OksmanCaldentey KM (2005a) Bioactive berry compoundsnovel tools against human pathogens. Appl Microbiol Biotechnol., 67:8-19. [PubMed]

25. Ruberto G, Baratta MT, Deans SG, Dorman HJ (2000). Antioxidant and antimicrobial activity of Foeniculum vulgare and Crithmum maritimum essential oils. Planta Medica;66(8):687-693

26. Shokryazdan P, Sieo CC, Kalavathy R, Liang JB, Alitheen, NB, Faseleh Jahromi M, Ho Y W (2014). Probiotic potential of Lactobacillus strains with antimicrobial activity against some human pathogenic strains. BioMed research international.

27. Tannock GW(1995). Microecology of the gastrointestinal tract in relation to lactic acid bacteria. International Dairy Journal 5, 1059-1070.

28. Vigors S, O’Doherty JV, Kelly AK, O'Shea CJ, Sweeney T (2016). The effect of divergence in feed efficiency on the intestinal microbiota and the intestinal immune response in both unchallenged and lipopolysaccharide challenged ileal and colonic explants. PLoS ONE 11, e0148145.

29. Viveros A, Chamorro S, Pizarro M, Arija I, Centeno C, Brenes A (2011). Effects of dietary polyphenol-rich grape products on intestinal microflora and gut morphology in broiler chicks. Poultry science, 90(3), 566-578.

30. Wei A, Shibamoto T (2007). Antioxidant activities and volatile constituents of various essential oils. Journal of agricultural and food chemistry, 55(5), 1737-1742.

31. Windisch W, Schedle K, Plitzner C, Kroismayr A (2008). Use of phytogenic products as feed additives for swine and poultry 1. Journal of animal science, 86(14_suppl), E140-E148. 